\title{
The Corporate Responsibility Paradox: A Multi-National Investigation of Business Traveller Attitudes and Their Sustainable Travel Behaviour
}

\author{
Philip R. Walsh ${ }^{1} @$, Rachel Dodds ${ }^{2}$, Julianna Priskin ${ }^{3}$, Jonathon Day ${ }^{4, *} \mathbb{(}$ and Oxana Belozerova ${ }^{5}$ \\ 1 Ted Rogers School of Business Management, Ryerson University, Toronto, ON M5B 2K3, Canada; \\ prwalsh@ryerson.ca \\ 2 Ted Rogers School of Hospitality and Tourism Management, Ryerson University, \\ Toronto, ON M5B 2K3, Canada; R2dodds@ryerson.ca \\ 3 Intitite of Tourism and Mobility, Lucerne School of Business, 6002 Lucerne, Switzerland; \\ julianna.priskin@hslu.ch \\ 4 School of Hospitality and Tourism Management, Purdue University, West Lafayette, IN 47907, USA \\ 5 Department of Socio-Economic Geography and Tourism, North-Caucasus Federal University, \\ 355017 Stavropol, Russia; obelozerova@ncfu.ru \\ * Correspondence: gjday@purdue.edu
}

Citation: Walsh, P.R.; Dodds, R.; Priskin, J.; Day, J.; Belozerova, O. The Corporate Responsibility Paradox: A Multi-National Investigation of Business Traveller Attitudes and Their Sustainable Travel Behaviour. Sustainability 2021, 13, 4343.

https://doi.org/10.3390/su13084343

Academic Editor: Andrea Pérez

Received: 4 March 2021

Accepted: 7 April 2021

Published: 14 April 2021

Publisher's Note: MDPI stays neutral with regard to jurisdictional claims in published maps and institutional affiliations.

Copyright: (c) 2021 by the authors. Licensee MDPI, Basel, Switzerland. This article is an open access article distributed under the terms and conditions of the Creative Commons Attribution (CC BY) license (https:// creativecommons.org/licenses/by/ $4.0 /)$.

\begin{abstract}
The implementation of sustainability practices in the tourism system requires the participation of a variety of actors. While much research has focused on supply-side issues associated with sustainable tourism, there has been less focus on supply-side issues associated with consumer behaviour and business-related travel. This paper addresses the behaviours of this significant market segment. As behavioural change is seen as a key mechanism for achieving emission reduction, this paper focuses on behaviours of business travels from four countries: Canada, Switzerland, Russia and the U.S., using values-attitudes-behaviour (VAB) theory. We employ Principal Components Analysis to reduce the variables down to four factors and related factor scores. Stepwise multiple linear regression was then used to measure causal associations. The findings show how national cultures, demographics and values influence (although at different levels) the sustainable attitudes and behaviour of business travellers. These results have implications for future corporate travel policy. The recent impact of the COVID-19 global pandemic is also addressed.
\end{abstract}

Keywords: business travel; sustainability; travel behaviour; values; attitudes

\section{Introduction}

Facing increasingly significant global challenges, both environmental and social, there is a growing urgency for the adoption of sustainable development practices. Travel, a global phenomenon that generates significant social, environmental and economic impacts, has been called upon to adopt sustainability practices and contribute to broader sustainability goals. While conceptual appeal of sustainable travel to academics and policy-makers has been well documented [1,2], there has been frustration with the slow rate of adoption of these principles [3].

The implementation of sustainable travel is a complex activity requiring the action of a large number of actors, each undertaking a variety of actions. The impact of travel and tourism on climate change, as one of a number of important sustainability challenges to which it contributes, provides important insights on the implementation of effective interventions. Travel and tourism have been reported to be between $2.5-3 \%$ of global $\mathrm{CO}_{2}$ emissions, yet this figure is critiqued for not considering the supply chain which underpins that amount and it is argued that a true life-cycle or energy analysis needs to be undertaken in order to truly assess this impact [4]. Indeed, although the need to limit carbon emissions has been highlighted as a necessity for achieving sustainable tourism 
development [4], to date, "no country has presented a comprehensive strategy to achieve measurable emission reductions in tourism" [5] (p. 525). Even though there is increasing pressure for companies to mitigate their own unsustainable actions, especially as they are beginning to recognize that proactive corporate responsibility is a benefit or advantage to their corporation [6-8], when it comes to the impact of corporate travel it appears that company management considers employees travelling on business to be outside of their responsibility to control [9]. Achieving the desired goal of sustainable travel requires the actions of the corporation, through establishment of appropriate policies, to encourage pro-sustainability behaviours by the business traveller.

While there is an abundance of research about sustainable leisure tourism [10-18], there is little focus on business travel with a few notable exceptions discussed below. Therefore, this paper addresses two gaps. First, the majority of prior research in this area has been related to the leisure market and therefore there is a need to examine business travel further. Secondly, although some research exists on multi-country sustainable travel [15], there is a gap in the academic literature related to comparisons of multiple countries regarding sustainable business travel. Businesses are increasingly expected to commit to sustainability strategies because of rising public and shareholder pressure to do so [19]. Corporate spending related to sustainable activities in 2017 was estimated to be USD 611 billion [20] with diverse initiatives across organizations of all sizes and sectors, including investment in green information systems and sustainable travel [21]. There is some optimism that technology, such as videoconferencing technology, may reduce the need for travel, thereby reducing emissions. Evidence, however, suggests that the virtual workplace may not substantially limit business travel because the physical and virtual working environment are complementary, as opposed to substitutes, supporting the notion that business travel will remain strategic to the business and its ability to achieve its business outcomes [22]. In the past, econometric studies and executive surveys have highlighted the economic need for business travel's significant associated financial returns [23]. The recent global outbreak of COVID-19 shut down global business travel in the first few months of 2020 but a survey in May 2020 of the membership of the Global Business Travel Association (GBTA) indicated that more than half expected to resume business travel in the near future [24]. These early survey results are consistent with the findings by Cooper (2006) who found that travel in Asia rebounded quickly after the SARS outbreak when the implications of the pandemic were clearer and measures were taken to reduce the threat of infection [25]. In terms of personal behaviour, Senbeto and Han's (2020) study of tourism crises suggested that the effect of pandemics on personal profile and purpose of travel is anxiety-driven, so, given the apparent desire of firms to resume business travel, it is reasonable to expect that measures will be taken by companies and the travel industry to reduce employee anxiety [26]. Certainly, any positive experience during the past few months of using virtual meetings may encourage less business travel but it is unreasonable to expect that employees will not resume travelling on the business's behalf and therefore an obvious paradox remains for sustainably-minded firms when that travel is having a negative sustainability impact.

A significant sustainability focus in the past decade has been on the impact of air travel and related global emissions of greenhouse gases and recent studies have tended to focus on values, attitudes and behaviour towards sustainable travel from a single country perspective as shown in Table 1. Furthermore, some of that research has made specific reference to the role that business air travellers may have [27]. Lassen (2010) examined two Danish knowledge industry firms to identify what might connect the environmental attitudes of business travellers with their actual travel behaviour. The study referenced prior literature supporting different behaviours when travelling on business as opposed to leisure and his research confirmed that when it came to work-related air travel there appears to be an "exclusion of air travel from the environmental consciousness" [27] (p. 733) of business travellers. In a more recent study of business travellers in Taiwan, Lu and Wang (2018) also investigated attitudes and behaviours and had similar results that sug- 
gested business travellers do not consider the environmental impact their travel has. They included a frequency of business travel variables and found that the willingness to change travel behaviour to be more sustainable was only significantly associated with those who travelled the least [28]. This contrasted with earlier work that included both leisure and business travellers and where frequency of travel had a positive effect, although business travellers specifically indicated a reluctance to contribute more to sustainable travel if their organization did not compensate them [29].

Table 1. Summary of recent studies related to sustainable travel.

\begin{tabular}{cc}
\hline Study & Country \\
\hline van Birgelen et al. (2009) [30] & Netherlands \\
\hline Lassen (2010) [27] & Denmark \\
\hline Lu and Shon (2012) [29] & Taiwan \\
\hline Kroesen (2013) [31] & Netherlands \\
\hline Cheung et al. (2015) [32] & Taiwan \\
\hline Jou and Chen (2015) [33] & Switzerland \\
\hline Hinnen et al. (2015) [34] & United Kingdom \\
\hline Alcock et al. (2017) [35] & Taiwan \\
\hline Lu and Wang (2018) [28]
\end{tabular}

The literature on the relationship of attitudes to behaviour is extensive and has been applied to numerous jurisdictions, industries and sectors. Most research on this subject refers back to the work of Ajzen and Fishbein (1980) and their Theory of Reasoned Action (TRA) and Ajzen's (1991) subsequent Theory of Planned Behaviour (TPB) [36,37]. The application of these theories within the sustainability literature has also been substantial with the recognition that positive sustainable attitudes contribute to the development of positive sustainable behaviours [28,38]. The introduction of the influence of values on attitudes and behaviour can be attributed to Homer and Kahle (1988) who had found a lack of prior empirical causal modelling around the role that values have on influencing human behaviour [39]. They postulated that values are similar to attitudes but are a more abstract social cognition and therefore, antecedent to the development of attitudes and behaviours. While their work related to personal food shopping, since that time the values-attitudes-behaviour (VAB) theory has been applied to numerous research works where it has been found that sustainable values determine sustainable attitudes and in turn influence sustainable behaviour [40-44].

Researchers have also identified specific mediators that can be applied to the VAB model. For example, various literature has discussed the role of age and gender in the context of sustainable values, attitudes and behaviour. A general finding is that the younger and female demographic exhibits a more positive sustainable attitude [45-47] and HaskiLeventhal et al. (2017) found that the literature consistently supported a more positive level of attitude towards social responsibility and responsible management education on the part of females as opposed to males [48]. An examination of how age differences affect values and attitudes toward sustainable behaviours by Wiernik et al. (2013) relied on a meta-analysis of studies published over a 40-year period (1970-2010) and found that values were negligibly related to age while attitudes toward sustainable behaviour were slightly more positive with younger respondents [49]. Another identified mediator is the perceived knowledge regarding sustainability [50]. If an individual does not understand the concept of sustainability then their level of sustainable attitude and behaviour is likely to be limited [51]. The literature has been mixed in terms of the amount of influence that a person's knowledge [52,53] or familiarity $[54,55]$ with sustainability has on their sustainable values, attitudes or behaviour. The variety of results in the research related to specific mediators is likely due to the differing contexts associated with those studies, e.g., country, 
age group, industry. This is not unusual as Stern (2000) recognized that institutional factors (political, economic, social, technological and legal structures) can influence what values an individual may hold [56]. This includes the sustainability values that one might possess and how that then impacts the attitudes and behavioural commitment toward sustainable actions on the part of the individual [57].

Institutional factors are typically country-specific and a number of recent studies have examined the VAB model from a multi-country perspective. Ziegler (2017) found that environmental values were significant influencers of environmental attitudes for respondents measured in three countries: China, Germany and the U.S., with varying interaction effects associated with their political orientation [58]. In a study of undergraduate psychology students from Brazil, New Zealand and South Africa, it was found that environmental values and attitudes provide statistically significant explanations of variances in ecological behaviour, but varied enough to suggest that these values and attitudes are distinct to their respective social contexts. Furthermore, the findings supported the importance of identifying cultural differentiation when determining the prediction of sustainable behaviour [57]. In answering the question as to whether national values influence sustainable attitudes and behaviours, Minton et al. (2018) divided sustainable behaviours into normative (cultural standards and national infrastructure) and self-enhancing (motivated by self-interests) factions and examined the VAB relationship among 1064 participants from France, Japan and the U.S. [59]. They focused on the cultural value dimension of pragmatism because it represents how cultures address the challenges of the present and future while maintaining a link to their past and therefore emulates sustainability. Their finding was that across all three countries sustainable attitudes were strongly positive in their association with sustainable behaviours but that the effect of the national pragmatism value on sustainable attitudes differed between countries.

Accordingly, the model of analysis for this study is shown in Figure 1. Based on the literature as discussed above, the VAB model has been adapted to consider not only the hierarchal association of sustainable values to sustainable attitudes and behaviours but also the relative influences of age, gender, frequency of business travel and familiarity with the concept of sustainability. Furthermore, though there has been some study of sustainable tourism using a multi-country sample set [15], there is a gap in the academic literature related to multi-country comparisons of sustainable business travel. The purpose of this study is to compare and contrast the relationships between values, attitudes and behaviours of business travellers and the potential influencers using four countries: Canada, Russia, Switzerland and the United States.

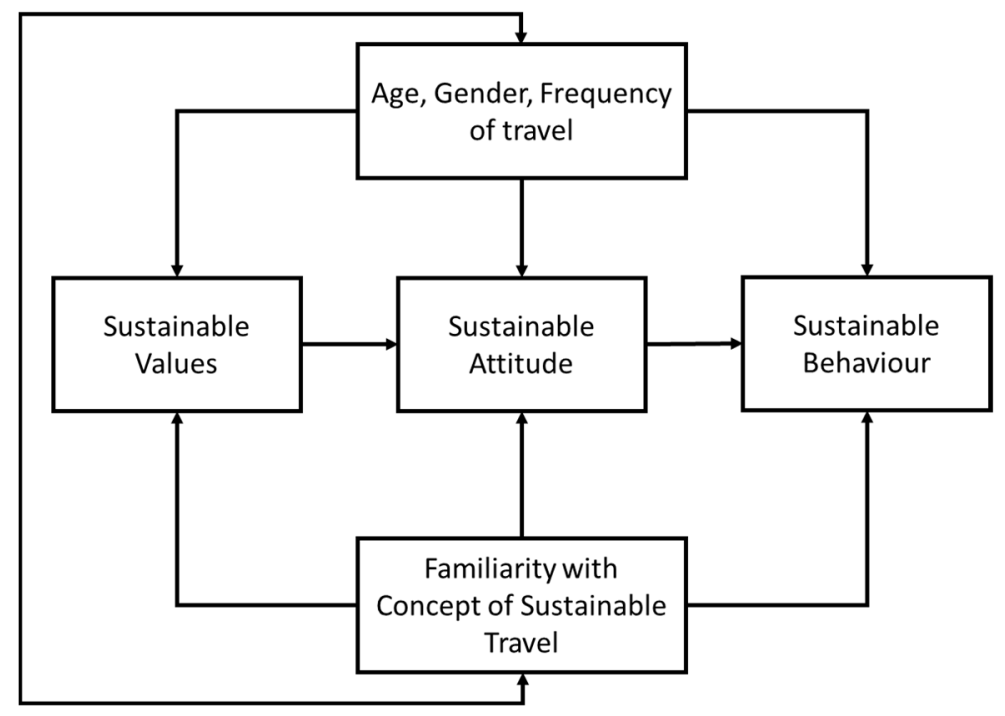

Figure 1. Sustainable Values, Attitudes, Behaviour (VAB) model with influencers. 


\section{Materials and Methods}

An online questionnaire instrument based on the literature was given to 679 business travellers from Russia, Switzerland, Canada and the United States who had travelled on business at least three times over the prior 12 months. The aim was to collect comparable information about business travellers in the four different countries with respect to a common set of indicators, which reflected sustainable business travel and business traveller behaviour. In this context, the survey included questions related to sustainable values, familiarity, attitudes and behaviours (Table 2). The questions were formulated using the simplest language possible and avoided any technical and academic expressions about sustainable business travel. The responses were either dichotomous (gender), continuous (age), nominal (frequency of business travel) or ordinal (values, familiarity, attitude and behaviour). A survey was administered online in Canada $(\mathrm{N}=161)$, Russia $(\mathrm{N}=157)$, Switzerland $(\mathrm{N}=161)$ and the USA $(\mathrm{N}=200)$. A polling company was engaged for data collection in each country. Data collection took place slightly differently in the four countries between November 2017 and August 2018. In Switzerland, the survey was administered in German in the German speaking part of the country. In the USA and Canada, the sample came from all across both nations and was administered in English and for Russia from the several regions and in Russian.

A total of 19 sustainable attitudinal and behavioural variables were measured on either five-point rating scales or seven-point rating scales. Principal components analysis with varimax rotation was applied to reduce the variables to a smaller number of latent variables or factors without limiting the explanation of variance. Factors were identified using Kaiser-criterion (Eigenvalues $>1$ ) and factor loadings $<0.5$ were suppressed. A factor score for each of the resulting four factors (comprised of one set of sustainable attitude variables and three sets of behavioural variables) were correlated with the age, gender, frequency of business travel, familiarity and personal values variables using both Pearson and Spearman rho (depending on whether one of the variables was parametric or not). Certain descriptive statistics were determined for the specific country responses, such as the mean, median, standard deviation, skewness and kurtosis, were undertaken for each of the four-country sample and linear regression was used to measure causality between the independent variables and the various dependent behavioural variables. 
Table 2. Questionnaire Framework.

Model Elements

Age-Please state your age in years

Gender-Please indicate which gender you identify with

Influencers $\quad$ Frequency of Business Travel-

How many times did you travel for a business/professional purpose involving at least one overnight stay?

Familiarity with concept of sustainable travel-How familiar are you with the meaning of sustainable tourism?

Sustainable Values

For me personally, doing good things for nature and the planet is important

How concerned are you about exploitation of children?

How concerned are you about gender equality?

How concerned are you about for fair pay for local workers?

Sustainable Attitudes How concerned are you about the amount of emissions from travel and tourism?

How concerned are you about the extent of recycling?

How concerned are you about the overuse of water?

How concerned are you about the unfair treatment of staff and employees?

During planning a business trip, how often did you consider the negative impacts of a trip? (for example, emissions)

Did you ever choose NOT to go on a trip to a destination to avoid causing negative impacts?

To what extent did you offset emissions or buy compensation certificates for your transport related emissions?

To what extent did you opt for a different destination that did not need flying to.

To what extent did you rent a private car at my destination (negative behavior)

To what extent did you take a taxi instead of using public transport at my destination (negative behavior)

To what extent did you think about your overall energy consumption related to the trip.

To what extent did you choose accommodation that was operated on renewably sourced power (like solar, wind or others).

To what extent did you keep the air conditioning on when you left the room.(negative behavior)

To what extent did you use a refillable drink bottle.

To what extent did you recycle my paper, glass, cans, plastics etc. waste where possible.

When you planned your business trip(s) how important were sustainability aspects?
$[28,29,40,47,48,51-55,57,60]$

$[61-63]$

$[9,13,15,28,31,35,73,77-93]$ 


\section{Results}

The outcome of the principal component factor analysis after varimax rotation is shown in Table 3. The adequacy of sampling for conducting the analysis was confirmed (Kaiser-Meyer-Olkin [KMO] equal to 0.897, Barlett's Test of Sphericity $p=0.000$ ). A single attitudes factor and three distinct behavioural factors: sustainable behaviour pre-trip, negative sustainable behaviour related to the use of transportation and energy during the trip and sustainable behaviour related to reducing waste during the trip, were identified. The total variance explained through the factors was $64.94 \%$ and the internal scale reliabilities of the factors are reasonable to very good given the Cronbach's alpha scores that range from $\sim 0.7$ to $\sim 0.9$. The revised model of analysis is shown in Figure 2. The raw scores of all items in each factor were summed to provide a factor score. The resulting factor scores were used in further statistical analysis.

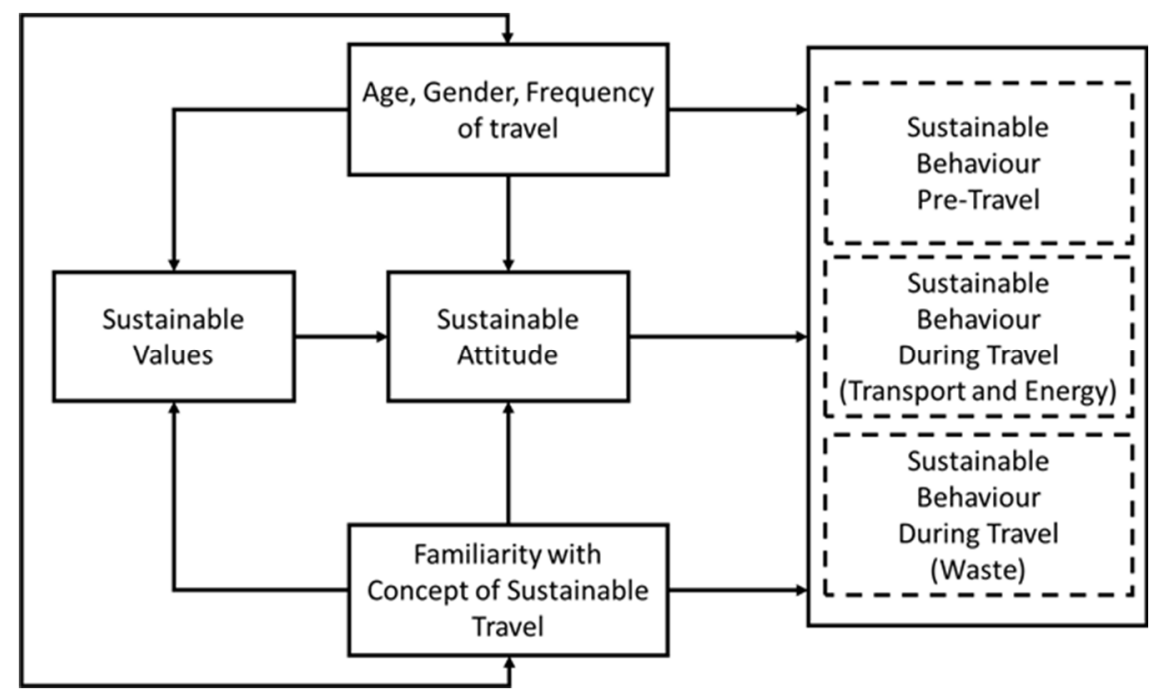

Figure 2. Revised model of analysis.

\subsection{Country Comparison of Descriptive Measures}

In terms of the descriptive variable measures (Table 4), there were more male respondents than female for all countries (53 to $56 \%$ male), with Russia having the greater percentage of female business travellers. Average ages for the respondents for Canada, Russia and Switzerland were in the mid to high 40s but the U.S. survey respondents were notably younger, having a mean age of 37 . This age difference likely had some influence on the levels of familiarity, values and attitudes of the American respondents. The frequency of business travel as measured by the number of business trips per year averaged slightly less than five times per year, with Russians travelling the least and Canadians the most. The level of familiarity with sustainable travel was highest with the American business traveller, followed by the Swiss and Canadians, with only the Russians on average being less familiar with the concept (possibly connected with fact that, in Russian terminology, there are other widely spread notions with similar meanings, for example, the notion of environmental protection which studies the connection of some cultural and economic dimensions of sustainability). For example, in an investigation of the understanding of sustainable tourism among Russian tourism managers, Kask et al. (2016) note that "data from the interviews illustrated that respondents associated a variety of terms with the phenomena of sustainable tourism" [94] (p. 103). However, all business travellers in the four countries rated "doing good for people and societies" and "doing good for nature and the planet" as being personally important with moderate to significant skews towards the extremely important. American, Swiss and Canadian business travellers (in that order) exhibited levels of attitudes towards sustainability consistent with their responses to familiarity and personal values. The Russian business travellers however, exhibited a significant 
difference in their attitude towards sustainability even though their personal values on sustainability were equal to those from the other three countries.

With the behavioural responses, only the U.S. business traveller, on average, exhibited sustainable behaviours when planning their business trip. Their responses have a slight skew towards pre-trip sustainable behaviour, but the kurtosis highlights the broad range of behaviour. For the other three countries it was found, on average, that considering sustainability in the planning of their business trip was generally not important. For Canadian business travellers, there is a moderate skew towards a lack of sustainable behaviour when planning their business trip while the Swiss and Russian business travellers are more normally, yet broadly, distributed around the mean. In examining the sustainable behaviour of the business travellers during their trips, there are two distinct sets of activities; those related to transportation and energy and activities related to waste. With the former, the measures are related to negative sustainable behaviour as discussed earlier. The results suggest that while American business travellers maintained the greatest level of sustainable attitude among the four countries measured, their behaviour is also the worst when it comes to using sustainable transport or reducing energy consumption. Canadian business travellers were slightly better but on average were inclined to also exhibit negative behaviour. The Swiss were more positive in behaving sustainably when it came to their use of transport and energy, but it was the Russian business traveller who was found to have limited the negative impact of their transportation and energy needs the most. The Russian data also showed a stronger skew towards limiting their impact. The final behavioural measure was related to the reduction of waste while travelling. Swiss, American and Canadian business travellers tended to avoid waste when travelling. The data show that both the Swiss and American business travellers' responses were strongly skewed towards positive sustainable behaviour when it came to managing their waste. For the overall skewness and kurtosis of the data, the absolute values for all variables measured fell within acceptable levels of normality (1.96 for skewness, 3.29 for kurtosis) for univariate distribution [95].

\subsection{Country Comparison of Significant Relationships}

When considering if there are any statistically significant associations that differ between business travellers from the four countries, non-parametric correlation (Spearman $\rho$ ) was undertaken when either or both variables are nominal or ordinal in nature while parametric correlation (Pearson) was used for continuous variables. The results (Table 5) show some distinct differences and similarities between them.

\subsubsection{Gender}

Some moderate to moderately weak relationships exist between gender and the other measures. Swiss and Canadian males tended to be older and for Russian business travellers it is men who were slightly more likely to be doing the travelling; however, when acting more sustainably in terms of choosing transport and using energy, it is more likely to be the female business traveller who does so. Canadian female business travellers tend to be more familiar with the meaning of sustainable tourism and along with Swiss female business travellers were more likely to value sustainability, maintain a greater attitude towards sustainability and behave more sustainably than their male counterparts.

\subsubsection{Age}

For Canadian and American business travellers, a younger age is significantly but moderately associated with sustainable pre-travel behaviour and to a lesser degree familiarity with sustainable tourism, but sustainable behaviour during travel in terms of the use of transportation or energy is more associated with the older traveller. For Swiss business travellers it is slightly to moderately more likely that older travellers will be more familiar with the concept and exhibit sustainable values and attitudes; however, this does not translate into sustainable behaviour. In Russia, a younger age had a moderately weak association with the number of business trips taken in the prior 12 months-i.e., the younger took 
more business trips, but it is the older Russian business traveller who is slightly more likely to behave more sustainably with their choice of transport and energy usage.

\subsubsection{Number of Business Trips}

There is a moderately strong negative association between the level of business trip activity and the Russian business traveller's familiarity with sustainable travel and sustainable values and attitude. However, this does not appear to translate significantly to their behaviour as there is only a moderately week association with their behaviour towards waste when they travel. For Canadians, there was a moderately strong positive association between the number of business trips they took and their behaviour towards limiting waste.

\subsubsection{Familiarity}

The level of familiarity with the meaning of sustainable tourism was generally significantly associated, to varying degrees, with sustainability values, attitudes and behaviours for all four countries. These associations were the strongest with Canadians and Americans and weakest with the Russian business traveller.

\subsubsection{Values}

As would be expected, the importance of personally doing good for people and societies is strongly associated with the importance of personally doing something good for nature and the planet. When the level of valuing sustainability is compared with sustainability attitudes the distinction between countries becomes evident. Canadian and American business travellers who rate their sustainable values highly are the most likely to maintain a greater attitude towards sustainability followed closely by the Swiss, but the association with their sustainable behaviours are more subdued in comparison especially during their business travel. Russian business travellers have a more modest association between how they value sustainability and their sustainability attitude and there appears to be no relationship at all with how they behave when travelling on business.

\subsubsection{Attitude}

For all four countries, there is a moderate to strong association between sustainability attitude and sustainable behaviour prior to travelling for business travellers and this seems to translate through to their reduction of waste when travelling. However, for Canadian and American business travellers the attitude-behaviour relationship with respect to the use of transportation and energy suggests a tendency to behave unsustainably, irrespective of their higher level of sustainable attitudes.

\subsubsection{Behaviour}

Sustainable behaviour pre-travel was moderately associated with reducing waste while traveling for Russian, Canadian and American business travellers, with the exception being with the Swiss, where there was no significant association. There were mixed results when comparing the sustainable use of transport and energy with the generation of waste. No significant association was found between either for Canadians and Russians. A moderately positive association exists with the Swiss business traveller suggesting a mutual tendency to behave sustainably on both measures during their travel while a moderately negative association exists for American business travellers indicating a disconnect between their behaviour when travelling. This disconnect is even more severe when testing the association of their pre-travel sustainable behaviour and the sustainable use of transportation and energy. The strongly significant negative correlation $\left(-0.634^{* *}\right)$ emphasizes the extreme dissonance that exists with American business travellers. Canadians also exhibited this negative association with only slightly less severity $\left(-0.567^{* *}\right)$, while a significantly weaker association existed with the Russian business travellers $(-0.180 *)$. 
Table 3. Principal Component Analysis.

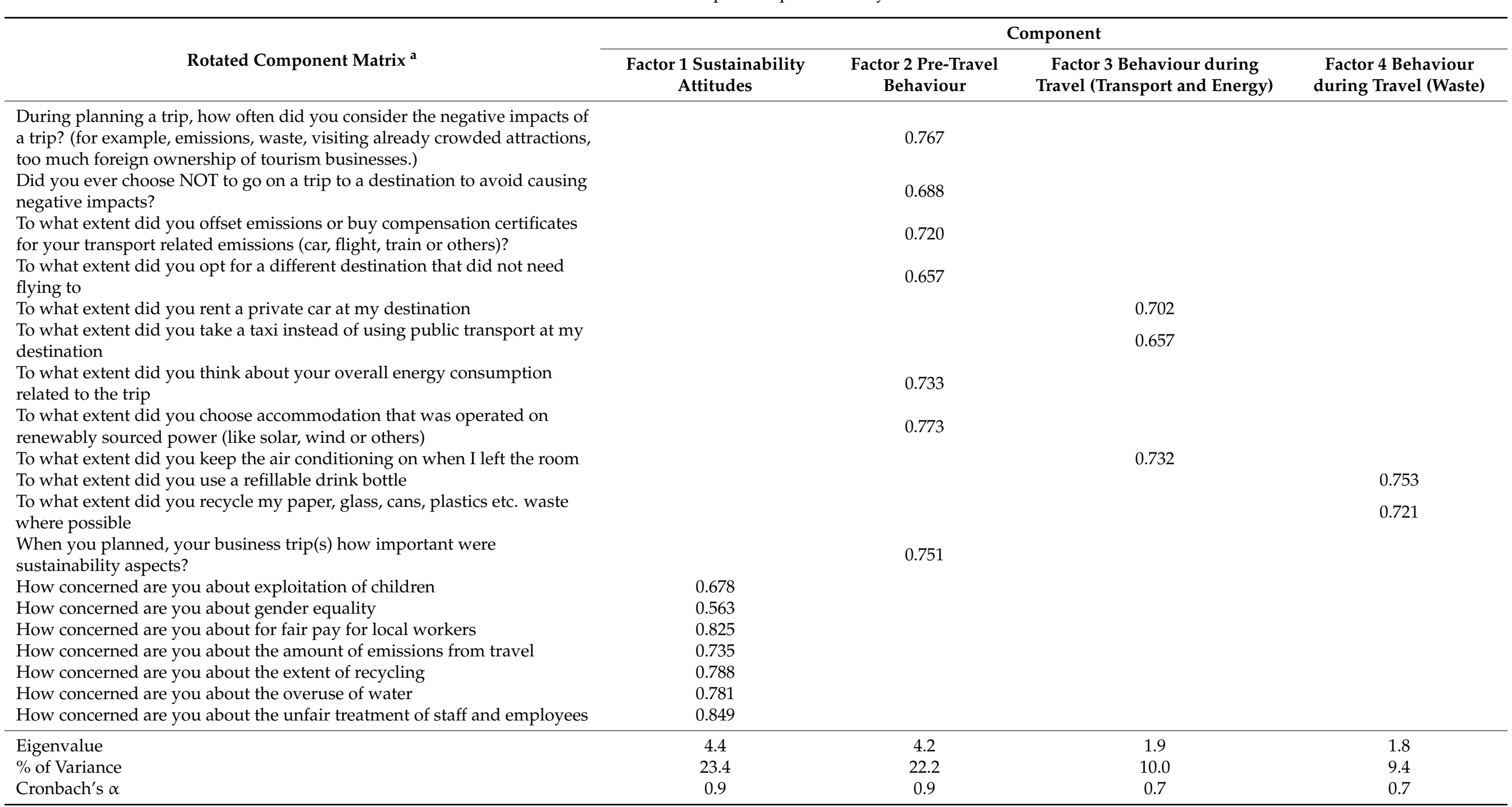

Extraction Method: Principal Component Analysis. Rotation Method: Varimax with Kaiser Normalization. ${ }^{a}$ Rotation converged in 6 iterations. 
Table 4. Descriptive Statistics.

\begin{tabular}{|c|c|c|c|c|c|c|c|c|c|c|c|}
\hline & & Gender & $\begin{array}{c}\text { Age } \\
\text { (Years) }\end{array}$ & $\begin{array}{l}\text { Number of } \\
\text { Business } \\
\text { Trips in Past } \\
12 \text { Months }\end{array}$ & $\begin{array}{c}\text { How Familiar } \\
\text { Are you with } \\
\text { the Meaning } \\
\text { of Sustainable } \\
\text { Tourism? } \\
1=\text { Never } \\
7=\text { Extremely } \\
\text { Familiar }\end{array}$ & $\begin{array}{c}\text { How } \\
\text { Important Is } \\
\text { It for You } \\
\text { Personally to } \\
\text { Do Good for } \\
\text { People and } \\
\text { Societies } \\
1=\text { Not } \\
\text { Important } \\
7=\text { Very } \\
\text { Important }\end{array}$ & $\begin{array}{c}\text { How } \\
\text { Important Is } \\
\text { It for You } \\
\text { Personally } \\
\text { to Do Good } \\
\text { Things for } \\
\text { Nature and } \\
\text { the Planet } \\
1=\text { Not } \\
\text { Important } \\
7 \text { = Very } \\
\text { Important }\end{array}$ & $\begin{array}{l}\text { Sustainability } \\
\text { Attitudes } \\
\text { (Max } \\
\text { Score }=49)\end{array}$ & $\begin{array}{c}\text { Sustainable } \\
\text { Behaviour: } \\
\text { Pre-Travel } \\
(\text { Max } \\
\text { Score = 41) }\end{array}$ & $\begin{array}{l}\text { Negative } \\
\text { Sustainable } \\
\text { Behaviour: } \\
\text { during Travel } \\
\text { (Transporta- } \\
\text { tion and } \\
\text { Energy) } \\
\text { (Max } \\
\text { Score }=-17)\end{array}$ & $\begin{array}{c}\text { Sustainable } \\
\text { Behaviour: } \\
\text { during } \\
\text { Travel } \\
\text { (Waste) } \\
\text { (Max } \\
\text { Score }=10)\end{array}$ \\
\hline \multirow{5}{*}{ Russia } & $\mathrm{N}$ & 157 & 157 & 157 & 157 & 157 & 157 & 157 & 157 & 157 & 157 \\
\hline & Mean & 1.618 & 2.580 & 4.420 & 3.229 & 5.427 & 5.108 & 24.752 & 14.497 & -5.529 & 4.185 \\
\hline & $\mathrm{SD}$ & 0.487 & 1.236 & 0.495 & 2.148 & 1.737 & 2.005 & 9.783 & 5.064 & 2.252 & 2.180 \\
\hline & Skewness & -0.490 & 0.269 & 0.326 & 0.417 & -1.095 & -0.702 & -0.252 & 0.173 & -1.340 & 0.655 \\
\hline & Kurtosis & -1.783 & -1.083 & -1.919 & -1.188 & 0.300 & -0.743 & -0.328 & -1.269 & 1.438 & -0.734 \\
\hline \multirow{4}{*}{ Swiss } & $\mathrm{N}$ & 161 & 161 & 161 & 161 & 161 & 161 & 161 & 161 & 161 & 161 \\
\hline & Mean & 1.658 & 47.044 & 4.758 & 4.497 & 5.534 & 5.478 & 35.870 & 16.832 & -7.944 & 8.286 \\
\hline & Skewness & -0.674 & -0.378 & 0.449 & -0.457 & -1.030 & -0.997 & -0.941 & 0.366 & -0.201 & -1.303 \\
\hline & Kurtosis & -1.565 & -0.594 & -1.192 & -0.606 & 1.669 & 1.108 & 1.454 & -0.840 & -0.688 & 1.940 \\
\hline \multirow{5}{*}{ Canada } & $\mathrm{N}$ & 161 & 161 & 161 & 161 & 161 & 161 & 161 & 160 & 161 & 161 \\
\hline & Mean & 1.689 & 45.640 & 4.820 & 4.373 & 5.590 & 5.584 & 34.534 & 16.531 & -8.857 & 6.447 \\
\hline & $\mathrm{SD}$ & 0.477 & 11.446 & 0.749 & 2.040 & 1.403 & 1.363 & 11.080 & 9.414 & 3.072 & 1.887 \\
\hline & Skewness & -0.651 & 0.047 & 0.308 & -0.329 & -1.026 & -0.997 & -0.683 & 0.924 & -0.373 & -0.151 \\
\hline & Kurtosis & -1.123 & -0.762 & -1.159 & -1.088 & 0.932 & 1.068 & -0.225 & -0.323 & -0.431 & -0.481 \\
\hline \multirow{5}{*}{ U.S. } & $\mathrm{N}$ & 200 & 200 & 200 & 200 & 195 & 195 & 200 & 200 & 200 & 200 \\
\hline & Mean & 1.700 & 36.740 & 4.505 & 5.350 & 5.826 & 5.949 & 37.205 & 22.125 & -10.750 & 7.745 \\
\hline & SD & 0.459 & 9.332 & 0.501 & 1.807 & 1.533 & 1.222 & 10.623 & 7.836 & 2.504 & 1.840 \\
\hline & Skewness & -0.879 & 0.933 & -0.02 & -1.087 & -1.575 & -1.598 & -1.391 & -0.666 & 0.547 & -1.148 \\
\hline & Kurtosis & -1.239 & 1.279 & -2.02 & 0.177 & 2.15 & 3.406 & 1.895 & -0.683 & 0.062 & 1.226 \\
\hline
\end{tabular}


Table 5. Correlation coefficients (Spearman rho for V1 to V6 Pearson for A1, B1-B3)

\begin{tabular}{|c|c|c|c|c|c|c|c|c|c|c|c|c|c|c|c|c|c|c|c|c|}
\hline & \multicolumn{4}{|c|}{$\begin{array}{c}\text { Gender } \\
\text { (V1) }\end{array}$} & \multicolumn{4}{|c|}{$\begin{array}{l}\text { Age } \\
\text { (V2) }\end{array}$} & \multicolumn{4}{|c|}{ Number of Business Trips in the Past 12 Months } & \multicolumn{4}{|c|}{$\begin{array}{l}\text { How Familiar Are You with the Meaning of } \\
\text { Sustainable Tourism? } \\
\text { (V4) }\end{array}$} & \multicolumn{4}{|c|}{$\begin{array}{l}\text { How Important Is It for You Personally to Do } \\
\text { Good for People and Societies? } \\
\text { (V5) }\end{array}$} \\
\hline & Russia & Swiss & Canada & U.S. & Russia & Swiss & Canada & U.S. & Russia & Swiss & Canada & U.S. & Russia & Swiss & Canada & U.S. & Russia & Swiss & Canada & U.S. \\
\hline $\mathrm{n}=$ & 157 & 161 & 161 & 200 & 157 & 161 & 161 & 200 & 157 & 161 & 161 & 200 & 157 & 161 & 161 & 200 & 157 & 161 & 161 & 195 \\
\hline V1 & - & - & - & - & NS & $0.254 * *$ & 0.238 ** & NS & $0.218^{* *}$ & NS & NS & NS & NS & NS & $-0.214 * *$ & NS & NS & $-0.196^{*}$ & -0.208 ** & $-0.147 *$ \\
\hline V2 & & & & & - & - & - & - & -0.194 ** & NS & NS & NS & NS & $0.181 *$ & $-0.246^{* *}$ & $-0.210^{* *}$ & NS & $0.258 * *$ & NS & NS \\
\hline V3 & & & & & & & & & - & - & - & - & $-0.463 * *$ & NS & 0.181 * & NS & -0.246 ** & NS & NS & NS \\
\hline \multirow[t]{3}{*}{$\mathrm{V} 4$} & & & & & & & & & & & & & - & - & - & - & NS & $0.192 *$ & $0.338 * *$ & $0.321^{* *}$ \\
\hline & \multicolumn{4}{|c|}{$\begin{array}{l}\text { How Important Is It for You to Do Something } \\
\text { Good for Nature and the PLANET? } \\
\text { (V6) }\end{array}$} & \multicolumn{4}{|c|}{$\begin{array}{c}\text { Sustainability Attitudes } \\
\text { (A1) }\end{array}$} & \multicolumn{4}{|c|}{$\begin{array}{c}\text { Sustainable Behaviour Pre-Travel } \\
\text { (B1) }\end{array}$} & \multicolumn{4}{|c|}{$\begin{array}{l}\text { Negative Sustainable Behaviour during Travel } \\
\text { (Transportation and Energy) } \\
\text { (B2) }\end{array}$} & \multicolumn{4}{|c|}{$\begin{array}{c}\text { Sustainable Behaviour during Travel (Waste) } \\
\text { (B3) }\end{array}$} \\
\hline & Russia & Swiss & Canada & U.S. & Russia & Swiss & Canada & U.S. & Russia & Swiss & Canada & U.S. & Russia & Swiss & Canada & U.S. & Russia & Swiss & Canada & U.S. \\
\hline $\mathrm{n}=$ & 157 & 161 & 161 & 195 & 157 & 161 & 161 & 200 & 157 & 161 & 160 & 200 & 157 & 161 & 161 & 200 & 157 & 161 & 161 & 200 \\
\hline V1 & NS & $-0.178 *$ & $-0.214 * *$ & NS & NS & $-0.164 *$ & -0.280 ** & NS & NS & -0.226 ** & -0.276 ** & $0.192 * *$ & -0.220 ** & $-0.222 * *$ & NS & NS & NS & $-0.283 * *$ & -0.257 ** & NS \\
\hline V2 & NS & $0.253 * *$ & NS & NS & NS & $0.210^{* *}$ & NS & NS & NS & NS & $-0.400^{* *}$ & -0.398 ** & $0.172 *$ & NS & $0.311 * *$ & $0.172 *$ & $-0.173 *$ & NS & NS & NS \\
\hline V3 & $-0.373 * *$ & NS & NS & NS & -0.363 ** & NS & $0.168 *$ & NS & NS & NS & NS & $0.150 *$ & NS & NS & NS & $-0.185 * *$ & -0.215 ** & NS & $0.479 * *$ & NS \\
\hline V4 & $0.173 *$ & $0.292 * *$ & $0.361^{* *}$ & 0.303 ** & $0.420^{* *}$ & $0.357 * *$ & $0.567^{* *}$ & 0.548 ** & NS & $0.357^{* *}$ & 0.627 ** & 0.550 ** & $-0.163 *$ & NS & $-0.321 * *$ & $-0.536 * *$ & NS & $0.172 *$ & $0.336 * *$ & 0.350 ** \\
\hline V5 & $0.709 * *$ & $0.745^{* *}$ & 0.803 ** & 0.699 ** & 0.283 ** & $0.479 * *$ & $0.624 * *$ & $0.587^{* *}$ & NS & $0.303 * *$ & $0.321 * *$ & NS & NS & NS & $-0.186^{*}$ & $-0.188 * *$ & NS & $0.276 * *$ & 0.194 * & $0.289 * *$ \\
\hline V6 & - & - & - & - & 0.219 ** & $0.584 * *$ & $0.671^{* *}$ & $0.617^{* *}$ & NS & 0.414 ** & 0.435 ** & NS & NS & $0.193 *$ & NS & NS & NS & $0.328 * *$ & 0.305 ** & $0.307 * *$ \\
\hline A1 & & & & & - & - & - & - & $0.550 * *$ & $0.396 * *$ & $0.527^{* *}$ & $0.443 * *$ & NS & NS & $-0.202 *$ & $-0.311^{* *}$ & $0.493 * *$ & $0.280 * *$ & 0.461 ** & $0.351^{* *}$ \\
\hline B2 & & & & & & & & & & & & & - & - & - & - & NS & $0.273 * *$ & NS & $-0.420^{* *}$ \\
\hline B3 & & & & & & & & & & & & & & & & & - & - & - & - \\
\hline
\end{tabular}




\subsection{Country Comparison of Causal Association}

Given the relative normality of the data using the factor scores and its continuous nature, stepwise multiple linear regression was performed to compare the four nationalities of business travellers and the relative causality of the dependent variables. In terms of causal associations, the relationship between attitudes and behaviour varies between countries as do the influences of age, gender and frequency of business travel. The results are summarized in Table 6 with sustainable behaviour models created for each behavioural factor and for each country. For all models, the Durbin-Watson test for issues related to multicollinearity fell within the acceptable range of 1.5 to 2.5 , the variance inflation factor (VIF) measures of multicollinearity were also acceptable $(<2)$ and the ANOVA significance $(p)$ were equal to or less than 0.001 , confirming the models are statistically significant.

\subsubsection{Sustainable Behaviour Pre-Travel}

Business travellers from all four countries have their pre-travel behaviours influenced by different combinations of explanatory variables to a significant degree with explanations of variance (R2) ranging from $24.9 \%$ (Swiss) to $55.1 \%$ (Canadian). For example, the model for the Canadian business travellers is strongly influenced by the level of familiarity they have of sustainable travel while in Russia and the United States, positive sustainability attitudes have the most dominant influence. For the Swiss model, sustainable behaviour pre-travel is influenced mainly by how much their values related to the natural environment.

\subsubsection{Sustainable Behaviour during Travel (Transportation and Energy Use)}

The explanatory power of the models related to sustainable behaviour during travel is much more subdued than that pre-travel. The level of positive attitudes to sustainability only contributes significantly to the behaviour of American business travellers. For Russian, Swiss and Canadian business travellers their sustainable transportation and energy use is influenced principally by younger and female business travellers, although as with sustainable behaviour pre-travel, familiarity with the meaning of sustainable travel also influenced Canadians.

\subsubsection{Sustainable Behaviour during Travel (Waste)}

As with sustainable behaviour pre-travel, sustainability attitude has the most significant influence on business travellers from Canada, Russia and the United States when it comes to their behaviour in reducing waste when they are travelling. For the Swiss business traveller, it is once again the level by which their values associated with the natural environment that has the greatest influence on their sustainability behaviour towards waste reduction. 
Table 6. Statistically significant causal relationships between attitudes, demography and behaviour.

\begin{tabular}{|c|c|c|c|c|c|c|c|c|c|c|}
\hline \multicolumn{11}{|c|}{ Sustainable Behaviour Pre-Travel } \\
\hline & Gender & Age & $\begin{array}{c}\text { Frequency of } \\
\text { Business Travel }\end{array}$ & $\begin{array}{l}\text { Familiarity with } \\
\text { Sustainable Travel }\end{array}$ & Social Values & $\begin{array}{l}\text { Environmental } \\
\text { Values }\end{array}$ & $\begin{array}{l}\text { Sustainability } \\
\text { Attitudes }\end{array}$ & Total $\mathbf{R}^{2}$ adj. & Durbin-Watson & ANOVA $p=$ \\
\hline Canada & - & 0.093 & - & 0.410 & - & - & 0.048 & 0.551 & 2.137 & 0.000 \\
\hline Russia & 0.028 & - & - & - & - & - & 0.298 & 0.326 & 2.238 & 0.000 \\
\hline Swiss & - & - & - & 0.075 & - & 0.166 & 0.014 & 0.249 & 2.032 & 0.000 \\
\hline U.S. & 0.039 & 0.112 & - & - & - & 0.028 & 0.237 & 0.416 & 1.934 & 0.000 \\
\hline \multicolumn{11}{|c|}{ Sustainable Behaviour during Travel (Transportation and Energy Use) } \\
\hline & Gender & Age & $\begin{array}{c}\text { Frequency of } \\
\text { Business Travel }\end{array}$ & $\begin{array}{c}\text { Familiarity with } \\
\text { Sustainable Travel }\end{array}$ & Social Values & $\begin{array}{c}\text { Environmental } \\
\text { Values }\end{array}$ & $\begin{array}{c}\text { Sustainability } \\
\text { Attitudes }\end{array}$ & Total $\mathbf{R}^{2}$ adj. & Durbin-Watson & ANOVA $p=$ \\
\hline Canada & - & 0.118 & - & 0.067 & - & - & - & 0.185 & 1.816 & 0.000 \\
\hline Russia & 0.053 & - & - & - & - & - & - & 0.053 & 1.653 & 0.000 \\
\hline Swiss & 0.039 & 0.034 & - & - & - & - & - & 0.073 & 2.111 & 0.001 \\
\hline U.S. & - & - & 0.024 & - & - & - & 0.129 & 0.153 & 2.107 & 0.000 \\
\hline \multicolumn{11}{|c|}{ Sustainable Behaviour during Travel (Waste) } \\
\hline & Gender & Age & $\begin{array}{l}\text { Frequency of } \\
\text { Business Travel }\end{array}$ & $\begin{array}{l}\text { Familiarity with } \\
\text { Sustainable Travel }\end{array}$ & Social Values & $\begin{array}{l}\text { Environmental } \\
\text { Values }\end{array}$ & $\begin{array}{c}\text { Sustainability } \\
\text { Attitudes }\end{array}$ & Total $\mathbf{R}^{2}$ adj. & Durbin-Watson & ANOVA $p=$ \\
\hline Canada & 0.015 & - & 0.227 & - & - & 0.018 & 0.156 & 0.416 & 1.667 & 0.000 \\
\hline Russia & - & 0.015 & - & - & - & 0.025 & 0.238 & 0.278 & 2.322 & 0.000 \\
\hline Swiss & 0.037 & - & - & - & - & 0.123 & - & 0.160 & 1.897 & 0.000 \\
\hline U.S. & - & - & - & - & - & - & 0.188 & 0.188 & 2.161 & 0.000 \\
\hline
\end{tabular}




\section{Discussion}

The results of this study are generally consistent with Homer and Kahle's (1988) VAB theory in that attitudes do influence behaviour [39]. With business travellers, however, the level of influence varies by the country of residence and whether that behaviour is prior to, or during, their business travels. In adding a comparative dimension that involves four different countries, this study found that national cultures, demographics and values influence (albeit at different levels) the sustainable attitudes and behaviour of business travellers. The variations in the level of influence are consistent with the original work of Stern (2000) who emphasized the role of social structures and institutional constraints in developing sustainable values [56]. For example, the Russian results are similar to recent research that found a lack of knowledge, adequate infrastructure and financial security has prevented Russians from choosing more sustainable modes of behaviour when compared to Europeans [96]. However, to the extent that the Russian business traveller does exhibit sustainable behaviour it is likely that it is because they are the ones who maintain a positive attitude towards sustainability. With Canadian business travellers it is those who have a significant familiarity with sustainable travel that will influence their level of sustainable behaviour pre-travel and to some degree with their use of transportation and energy. However, any sustainable behaviour while they travel will be more likely due to whether or not they are younger or are frequent business travellers, although their level of sustainable attitude will add to the likelihood of waste reduction behaviour. Furthermore, sustainable attitudes of Canadian business travellers do not appear to be the dominant predictor of sustainable behaviour. This finding is consistent with the work of Kennedy et al. 2009 who had similar results in terms of the apparent dissonance between pro-environmental values/attitudes and environmentally sustainable behaviour of Canadians [97].

The values-attitude-behaviour relationship is the most subdued with the Swiss business traveller. This study found that the Swiss were the least likely to follow through on their sustainable values/attitudes when travelling on business and that even if they were to behave sustainably in their pre-travel activities, the evidence would suggest that they would not behave sustainably when they did travel. This observation is similar to research in Switzerland on the willingness to purchase carbon offsets. That work has shown that a significant percentage of Swiss travellers (30\%) are not willing to consider purchasing them at all, that their willingness varies greatly across individuals depending upon the consumption context and that purchasing offsets are considered a complement rather than an alternative choice for mitigating climate change [98]. Minton et al. (2018) found that sustainable behaviour is mediated by sustainable attitudes for low pragmatism countries, such as the United States and that attitude itself may not necessarily influence certain self-enhancing behaviours given the tendency to be more suspicious of change and preferring to maintain the status quo and organization procedures [59]. This could explain, to some degree, the results pertaining to the U.S. business traveller who reported having the greatest levels of sustainable values and attitudes, when compared with business travellers from the other countries in this study, but whose sustainable behaviour during their travel is the least.

Regardless of nationality, there is an obvious dissonance that exists between business traveller values and attitudes and their behaviour when travelling. For the entire sample, personal familiarity, values and attitudes towards sustainability and sustainable travel are quite positive, but when asked to rate their sustainable behaviour when travelling on business, on average, they score relatively poorly. This result is not surprising given the likelihood of mis-aligned personal values and inconsistent corporate travel policies as suggested earlier by Lassen (2010) [27]. Furthermore, the sustainability research has found the values/attitude-behaviour gap to exist in a number of industry and societal contexts $[50,51,70]$ and this study adds the multi-country business traveller context to that literature. 


\section{Conclusions}

This study highlights the important role of business travellers and their firms as key actors in implementing corporate environmental sustainability programs. It contributes to the general CSR literature by providing evidence from four countries about the extent to which business travellers exercise considerable discretion over their behaviour but remain subject to institutional travel policies and desired environmentally friendly outcomes result when corporate policy and individual behaviour align. For business travellers, their level of familiarity with sustainable travel practices and related sustainability attitude may not be connected to exercising more sustainable behaviour because "structural mechanisms" within their companies associated with corporate travel have a greater influence on individual rationalities [27]. These structural mechanisms relate to established policies, processes and procedures that businesses use for corporate travel and the individual rationalities related to business-related travel can include the desire to feel more cosmopolitan, see the international trip as a formative journey, escape from everyday pressures and the opportunity to mix business with pleasure. These perks are seen as an indication of status within the firm and thereby have an impact on the personal behaviour of the business traveller [93]. Certainly, the institutional influences of each of the four countries would appear to have some moderating effect on individual rationality, but regardless of nationality, there can exist an obvious paradox between any strategic intent of the firm to promote sustainable strategies for itself and the muted sustainable behaviour of its employees. Such conflict can occur because of inadequate corporate sustainable performance evaluation processes, which can create an opaque view of the specific sustainability activities, or lack thereof, at the firm level, thus resulting in unidentified consequences [21,99]. Another possible explanation involves the concept of the locus of control and its influence on the sustainability attitude-behaviour gap. Management and employees travelling on business may consider the nature of their travel as being outside of their responsibility to control it [9]. Therefore, they are less inclined to consider their individual values and attitudes when travelling on business and will follow the organizational norms instead [97].

The study also provides a notable contribution to understanding the role of personal accountability in the context of a firm's CSR policies. Additionally, it highlights the differences values and attitudes have on sustainable consumer behaviour between the pre-trip planning and actual travel phases. The evidence from this study has implications for firms seeking to be recognized as sustainable organizations. They cannot assume that individual values and attitudes will result in sustainable travel behaviour. Without integrating sustainability into the structural mechanisms of the firm, or establishing a sustainable business travel as a norm, any direct influence by companies on employees to behave sustainably may be muted, thus leaving employees to treat their travel behaviour differently when doing so as part of their job. The managerial implications of the findings here mean that companies need to continue promoting a culture of sustainability into their day-to-day operations and encourage employees to behave sustainably when they do travel on business. There may need to be more concrete accountability mechanisms within firms besides general CSR policies that restrict air travel or compensate for purchasing carbon offsets, book green hotels and green transportation arrangements, which will alleviate the values/attitude-behaviour gap that appears to exist within the business travel industry. Limitations of this study include recognizing that the data was gathered pre-COVID-19 and therefore the impact of this global pandemic is likely to have an effect on personal behaviour and corporate policies; however, evidence from the SARS epidemic in the early 2000s has shown that recovery in travel can be quite rapid once the implied threats are reduced. Therefore, it is reasonable to expect that the comparative results of this study still hold merit. In addition, while attempts were made to be consistent in numbers surveyed in each country and the proper translation of questions into the respective native languages, some scope difference may exist given the survey was conducted between countries and gathered over a ten-month period. This may have affected results due to differing circumstances in each country over that time. Future longitudinal research may help to determine if trends 
are consistent over time and should contribute to the development by management of sustainably oriented companies and effective and specific mechanisms for achieving a less negative impact, such as with climate change, from their employees' business travels.

Author Contributions: Conceptualization, J.P., J.D., R.D., O.B. and P.R.W.; methodology, P.R.W., R.D., J.P., J.D., O.B.; software, P.R.W.; validation, P.R.W., R.D.; formal analysis, P.R.W.; investigation, J.P., J.D., R.D., O.B.; resources, J.P., J.D., R.D., O.B.; data curation, P.R.W., R.D., J.P.; writing-original draft preparation, P.R.W.; writing-review and editing, R.D., J.P., J.D., O.B.; visualization, P.R.W.; supervision, R.D.; project administration, J.P., J.D., R.D., O.B., P.R.W.; funding acquisition, J.P., J.D., R.D., O.B. All authors have read and agreed to the published version of the manuscript.

Funding: This research was initiated and partly funded part by the Institute of Tourism and Mobility (ITM) at Lucerne School of Business.

Data Availability Statement: The data presented in this study are available on request from the corresponding author. The data are not publicly available due to privacy policy. Personal data from survey respondents is not shared on a public space.

Acknowledgments: We are grateful to the assistance provided by Anna Wallebohr.

Conflicts of Interest: All the authors declare no conflict of interest.

\section{References}

1. Ruhanen, L.; Weiler, B.; Moyle, B.D.; McLennan, C.L.J. Trends and patterns in sustainable tourism research: A 25-year bibliometric analysis. J. Sustain. Tour. 2015, 23, 517-535. [CrossRef]

2. Lu, J.; Nepal, S.K. Sustainable tourism research: An analysis of papers published in the Journal of Sustainable Tourism. J. Sustain. Tour. 2009, 17, 5-16. [CrossRef]

3. Maxim, C. Sustainable tourism implementation in urban areas: A case study of London. J. Sustain. Tour. 2016, 24, 971-989. [CrossRef]

4. Lenzen, M.; Sun, Y.Y.; Faturay, F.; Ting, Y.P.; Geschke, A.; Malik, A. The carbon footprint of global tourism. Nat. Clim. Chang. 2018, 8, 522. [CrossRef]

5. Gössling, S.; Scott, D.; Hall, C.M. Challenges of tourism in a low-carbon economy. Wiley Interdiscip. Rev. Clim. Chang. 2013, 4, 525-538. [CrossRef]

6. Porter, M.E.; van der Linde, C. Green and competitive: Ending the stalemate. Harv. Bus. Rev. 1995, 120-134. Available online: https:/ /hbsp.harvard.edu/product/95507-PDF-ENG (accessed on 1 June 2020).

7. Forsyth, T. Environmental responsibility and business regulation: The case of sustainable tourism. Geogr. J. 1997, 163, 270-280. [CrossRef]

8. Wijaya, A.S. Company's Benefits in Corporate Social Responsibility in Hospitality Industry. Tax Account. Rev. $2014,4,1$.

9. Cohen, S.A.; Hanna, P.; Gössling, S. The dark side of business travel: A media comments analysis. Transp. Res. Part D Transp. Environ. 2018, 61, 406-419. [CrossRef]

10. Buffa, F. Young tourists and sustainability. Profiles, attitudes, and implications for destination strategies. Sustainability 2015, 7, 14042-14062. [CrossRef]

11. Dodds, R.; Graci, S.; Holmes, M. Does the tourist care? A comparison of tourists in Koh Phi Phi, Thailand and Gili Trawangan, Indonesia. J. Sustain. Tour. 2010, 18, 207-222. [CrossRef]

12. Dolnicar, S. Insights into sustainable tourists in Austria: A data-based a priori segmentation approach. J. Sustain. Tour. 2004, 12, 209-218. [CrossRef]

13. Dolnicar, S. Identifying tourists with smaller environmental footprints. J. Sustain. Tour. 2010, 18, 717-734. [CrossRef]

14. Han, H.; Yu, J.; Koo, B.; Kim, W. Vacationers' norm-based behavior in developing environmentally sustainable cruise tourism. $J$. Qual. Assur. Hosp. Tour. 2019, 20, 89-106. [CrossRef]

15. Juvan, E.; Dolnicar, S. Measuring environmentally sustainable tourist behaviour. Ann. Tour. Res. 2016, 59, 30-44. [CrossRef]

16. Kim, M.-S.; Stepchenkova, S. Altruistic values and environmental knowledge as triggers of pro-environmental behavior among tourists. Curr. Issues Tour. 2019, 23, 1575-1580. [CrossRef]

17. Liu, A.; Ma, E.; Qu, H.; Ryan, B. Daily green behavior as an antecedent and a moderator for visitors' pro-environmental behaviors. J. Sustain. Tour. 2020, 28, 1390-1408. [CrossRef]

18. Nickerson, N.P.; Jorgenson, J.; Bynum Boley, B. Are sustainable tourists a higher spending market? Tour. Manag. 2016, 54, 170-177. [CrossRef]

19. Walsh, P.R.; Dodds, R. Measuring the choice of environmental sustainability strategies in creating a competitive advantage. Bus. Strategy Environ. 2017, 26, 672-687. [CrossRef]

20. Corporate Knights. Global Corporate Green Investment and the UN Sustainable Development Goals. 2019. Available online: https:/ / www.corporateknights.com/reports/2019_corporate-green-investment/global-corporate-green-investments-unsdg-15518350/ (accessed on 21 May 2020). 
21. Corbett, J.; Webster, J.; Jenkin, T.A. Unmasking corporate sustainability at the project level: Exploring the influence of institutional logics and individual agency. J. Bus. Ethics 2018, 147, 261-286. [CrossRef]

22. Jones, I.; Faulconbridge, J.; Marsden, G.; Anable, J. Demanding business travel: The evolution of the Timespaces of business practice. In Demanding Energy; Palgrave Macmillan: Cham, Switzerland, 2018; pp. 257-277.

23. Oxford Economics. The Return on Investment of U.S. Business Travel. 2009. Available online: https://www.oxfordeconomics com/Media/Default/Industry\%20verticals/Tourism/US\%20Travel\%20Association-\%20ROI\%20on\%20US\%20Business \%20 Travel.pdf (accessed on 1 June 2020).

24. Condé Nast. How COVID-19 Will Change Business Travel. Condé Nast Traveller. 28 May 2020. Available online: https: / / www.cntraveler.com/story/how-covid-19-will-change-business-travel (accessed on 1 June 2020).

25. Cooper, M. Japanese tourism and the SARS epidemic of 2003. J. Travel Tour. Mark. 2006, 19, 117-131. [CrossRef]

26. Senbeto, D.L.; Hon, A.H. The impacts of social and economic crises on tourist behaviour and expenditure: An evolutionary approach. Curr. Issues Tour. 2020, 23, 740-755. [CrossRef]

27. Lassen, C. Environmentalist in business class: An analysis of air travel and environmental attitude. Transp. Rev. 2010, 30, 733-751. [CrossRef]

28. Lu, J.L.; Wang, C.Y. Investigating the impacts of air travellers' environmental knowledge on attitudes toward carbon offsetting and willingness to mitigate the environmental impacts of aviation. Transp. Res. Part D Transp. Environ. 2018, 59, 96-107. [CrossRef]

29. Lu, J.L.; Shon, Z.Y. Exploring airline passengers' willingness to pay for carbon offsets. Transp. Res. Part D Transp. Environ. 2012, 17, 124-128. [CrossRef]

30. van Birgelen, M.; Semeijn, J.; Behrens, P. Explaining pro-environment consumer behavior in air travel. J. Air Transp. Manag. 2011, 17, 125-128. [CrossRef]

31. Kroesen, M. Exploring people's viewpoints on air travel and climate change: Understanding inconsistencies. J. Sustain. Tour. 2013, 21, 271-290. [CrossRef]

32. Cheung, J.; Kragt, M.; Burton, M. The Awareness and Willingness of Air Travellers to Pay for Voluntary Carbon Offsets and Their Co-Benefits; Working Paper 1505; School of Agricultural and Resource Economics, University of Western Australia: Crawley, Australia, 2015.

33. Jou, R.C.; Chen, T.Y. Willingness to pay of air passengers for carbon-offset. Sustainability 2015, 7, 3071-3085. [CrossRef]

34. Hinnen, G.; Hille, S.L.; Wittmer, A. Willingness to pay for green products in air travel: Ready for take-off? Bus. Strategy Environ. 2017, 26, 197-208. [CrossRef]

35. Alcock, I.; White, M.P.; Taylor, T.; Coldwell, D.F.; Gribble, M.O.; Evans, K.L.; Cornerd, A.; Vardoulakisae, S.; Fleming, L.E. 'Green' on the ground but not in the air: Pro-environmental attitudes are related to household behaviours but not discretionary air travel. Glob. Environ. Chang. 2017, 42, 136-147. [CrossRef]

36. Ajzen, I.; Fishbein, M. Understanding Attitudes and Predicting Social Behavior; Prentice-Hall: Englewood-Cliffs, NJ, USA, 1980.

37. Ajzen, I. The theory of planned behaviour: Reactions and reflections. Psychol. Health 2011, 26, 1113-1127. [CrossRef]

38. Cheung, M.F.; To, W.M. An extended model of value-attitude-behavior to explain Chinese consumers' green purchase behavior. J. Retail. Consum. Serv. 2019, 50, 145-153. [CrossRef]

39. Homer, P.M.; Kahle, L.R. A structural equation test of the value-attitude-behavior hierarchy. J. Personal. Soc. Psychol. 1988, 54, 638. [CrossRef]

40. Kiatkawsin, K.; Han, H. Young travelers' intention to behave pro-environmentally: Merging the value-belief-norm theory and the expectancy theory. Tour. Manag. 2017, 59, 76-88. [CrossRef]

41. Hansla, A.; Gamble, A.; Juliusson, A.; Gärling, T. Psychological determinants of attitude towards and willingness to pay for green electricity. Energy Policy 2008, 36, 768-774. [CrossRef]

42. Papagiannakis, G.; Lioukas, S. Values, attitudes and perceptions of managers as predictors of corporate environmental responsiveness. J. Environ. Manag. 2012, 100, 41-51. [CrossRef] [PubMed]

43. Shin, Y.H.; Moon, H.; Jung, S.E.; Severt, K. The effect of environmental values and attitudes on consumer willingness to pay more for organic menus: A value-attitude-behavior approach. J. Hosp. Tour. Manag. 2017, 33, 113-121. [CrossRef]

44. Duarte, R.; Escario, J.J.; Sanagustín, M.V. The influence of the family, the school, and the group on the environmental attitudes of European students. Environ. Educ. Res. 2017, 23, 23-42. [CrossRef]

45. Yu, X. Is environment 'a city thing' in China? Rural-urban differences in environmental attitudes. J. Environ. Psychol. 2014, 38, 39-48. [CrossRef]

46. Ramayah, T.; Rahbar, E. Greening the environment through recycling: An empirical study. Manag. Environ. Qual. Int. J. 2013, 24, 782-801. [CrossRef]

47. Paço, A.; Lavrador, T. Environmental knowledge and attitudes and behaviours towards energy consumption. J. Environ. Manag. 2017, 197, 384-392. [CrossRef]

48. Haski-Leventhal, D.; Pournader, M.; McKinnon, A. The role of gender and age in business students' values, CSR attitudes, and responsible management education: Learnings from the PRME international survey. J. Bus. Ethics 2017, 146, 219-239. [CrossRef]

49. Wiernik, B.M.; Ones, D.S.; Dilchert, S. Age and environmental sustainability: A meta-analysis. J. Manag. Psychol. 2013, 28, 826-856. [CrossRef]

50. Joshi, Y.; Rahman, Z. Consumers' sustainable purchase behaviour: Modeling the impact of psychological factors. Ecol. Econ. 2019, 159, 235-243. [CrossRef] 
51. Vermeir, I.; Verbeke, W. Sustainable food consumption: Exploring the consumer attitude-behavioral intention gap. J. Agric. Environ. Ethics 2006, 19, 169-194. [CrossRef]

52. Stern, P.C.; Dietz, T.; Kalof, L. Value orientations, gender, and environmental concern. Environ. Behav. 1993, 25, 322-348. [CrossRef]

53. Vicente-Molina, M.A.; Fernández-Sáinz, A.; Izagirre-Olaizola, J. Environmental knowledge and other variables affecting proenvironmental behaviour: Comparison of university students from emerging and advanced countries. J. Clean. Prod. 2013, 61, 130-138. [CrossRef]

54. Nisiforou, O.; Charalambides, A.G. Assessing undergraduate university students' level of knowledge, attitudes and behaviour towards biodiversity: A case study in Cyprus. Int. J. Sci. Educ. 2012, 34, 1027-1051. [CrossRef]

55. Komppula, R.; Honkanen, A.; Rossi, S.; Kolesnikova, N. The impact of values on sustainable behaviour-A study among Russian and Finnish university students. Eur. J. Tour. Res. 2018, 19, 116-131.

56. Stern, P.C. Psychology and the science of human-environment interactions. Am. Psychol. 2000, 55, 523. [CrossRef]

57. Milfont, T.L.; Duckitt, J.; Wagner, C. A cross-cultural test of the value-attitude-behavior hierarchy. J. Appl. Soc. Psychol. 2010, 40, 2791-2813. [CrossRef]

58. Ziegler, A. Political orientation, environmental values, and climate change beliefs and attitudes: An empirical cross country analysis. Energy Econ. 2017, 63, 144-153. [CrossRef]

59. Minton, E.A.; Spielmann, N.; Kahle, L.R.; Kim, C.H. The subjective norms of sustainable consumption: A cross-cultural exploration. J. Bus. Res. 2018, 82, 400-408. [CrossRef]

60. Holden, A. Achieving a sustainable relationship between common pool resources and tourism: The role of environmental ethics. J. Sustain. Tour. 2005, 13, 339-352. [CrossRef]

61. Bansal, P. The corporate challenges of sustainable development. Acad. Manag. Perspect. 2002, 16, 122-131. [CrossRef]

62. Buerke, A.; Straatmann, T.; Lin-Hi, N.; Müller, K. Consumer awareness and sustainability-focused value orientation as motivating factors of responsible consumer behavior. Rev. Manag. Sci. 2017, 11, 959-991. [CrossRef]

63. Hategan, C.D.; Sirghi, N.; Curea-Pitorac, R.I.; Hategan, V.P. Doing well or doing good: The relationship between corporate social responsibility and profit in Romanian companies. Sustainability 2018, 10, 1041. [CrossRef]

64. Payne, A. Corporate social responsibility and sustainable development. J. Public Aff. Int. J. 2006, 6, 286-297. [CrossRef]

65. Tepelus, C.M. Social responsibility and innovation on trafficking and child sex tourism: Morphing of practice into sustainable tourism policies? Tour. Hosp. Res. 2008, 8, 98-115. [CrossRef]

66. Zapata Campos, M.J.; Hall, C.M.; Backlund, S. Can MNCs promote more inclusive tourism? Apollo tour operator's sustainability work. Tour. Geogr. 2018, 20, 630-652. [CrossRef]

67. Alarcón, D.M.; Cole, S. No sustainability for tourism without gender equality. J. Sustain. Tour. 2019, 27, 903-919. [CrossRef]

68. Winchenbach, A.; Hanna, P.; Miller, G. Rethinking decent work: The value of dignity in tourism employment. J. Sustain. Tour. 2019, 27, 1026-1043. [CrossRef]

69. Dangi, T.B.; Jamal, T. An integrated approach to sustainable community-based tourism. Sustainability 2016, 8, 475. [CrossRef]

70. Becken, S. How tourists and tourism experts perceive climate change and carbon-offsetting schemes. J. Sustain. Tour. 2004, 12, 332-345. [CrossRef]

71. Higham, J.; Reis, A.; Cohen, S.A. Australian climate concern and the 'attitude-behaviour gap'. Curr. Issues Tour. 2016, 19, 338-354. [CrossRef]

72. Lin, L.P. Industrial tourists' behavioral intention toward slow travel in Taiwan. J. Sustain. Tour. 2017, 25, 379-396. [CrossRef]

73. Miller, D.; Merrilees, B.; Coghlan, A. Sustainable urban tourism: Understanding and developing visitor pro-environmental behaviours. J. Sustain. Tour. 2015, 23, 26-46. [CrossRef]

74. Kasim, A.; Gursoy, D.; Okumus, F.; Wong, A. The importance of water management in hotels: A framework for sustainability through innovation. J. Sustain. Tour. 2014, 22, 1090-1107. [CrossRef]

75. Zoghbi-Manrique-de-Lara, P.; Aguiar-Quintana, T.; Suárez-Acosta, M.A. A justice framework for understanding how guests react to hotel employee (mis) treatment. Tour. Manag. 2013, 36, 143-152. [CrossRef]

76. Ottman, J. The New Rules of Green Marketing: Strategies, Tools, and Inspiration for Sustainable Branding; Routledge: Abingdon-onThames, UK, 2017.

77. Cavagnaro, E.; Staffieri, S. A study of students' travellers values and needs in order to establish futures patterns and insights. J. Tour. Futures 2015, 1, 94-107. [CrossRef]

78. Atherton, A.; Giurco, D. Campus sustainability: Climate change, transport and paper reduction. Int. J. Sustain. High. Educ. 2011, 12, 269-279. [CrossRef]

79. Prillwitz, J.; Barr, S. Moving towards sustainability? Mobility styles, attitudes and individual travel behaviour. J. Transp. Geogr. 2011, 19, 1590-1600. [CrossRef]

80. Dickinson, J.E.; Lumsdon, L.M.; Robbins, D. Slow travel: Issues for tourism and climate change. J. Sustain. Tour. 2011, 19, 281-300. [CrossRef]

81. Conway, D.; Timms, B.F. Are slow travel and slow tourism misfits, compadres or different genres? Tour. Recreat. Res. 2012, 37, 71-76.

82. Becken, S.; Simmons, D.; Frampton, C. Segmenting tourists by their travel pattern for insights into achieving energy efficiency. $J$. Travel Res. 2003, 42, 48-56. [CrossRef]

83. Kelly, J.; Haider, W.; Williams, P.W. A behavioral assessment of tourism transportation options for reducing energy consumption and greenhouse gases. J. Travel Res. 2007, 45, 297-309. [CrossRef] 
84. Signorile, P.; Larosa, V.; Spiru, A. Mobility as a service: A new model for sustainable mobility in tourism. Worldw. Hosp. Tour. Themes 2018, 10, 185-200. [CrossRef]

85. Martín Martín, J.M.; Guaita Martínez, J.M.; Molina Moreno, V.; Sartal Rodríguez, A. An Analysis of the Tourist Mobility in the Island of Lanzarote: Car Rental Versus More Sustainable Transportation Alternatives. Sustainability 2019, 11, 739. [CrossRef]

86. Font, X.; McCabe, S. Sustainability and marketing in tourism: Its contexts, paradoxes, approaches, challenges and potential. J. Sustain. Tour. 2017, 25, 869-883. [CrossRef]

87. Kostakis, I.; Sardianou, E. Which factors affect the willingness of tourists to pay for renewable energy? Renew. Energy 2012, 38, 169-172. [CrossRef]

88. Verma, V.K.; Chandra, B. An application of theory of planned behavior to predict young Indian consumers' green hotel visit intention. J. Clean. Prod. 2018, 172, 1152-1162. [CrossRef]

89. Navratil, J.; Picha, K.; Buchecker, M.; Martinat, S.; Svec, R.; Brezinova, M.; Knotek, J. Visitors' preferences of renewable energy options in green hotels. Renew. Energy 2019, 138, 1065-1077. [CrossRef]

90. Budeanu, A. Sustainable tourist behaviour-A discussion of opportunities for change. Int. J. Consum. Stud. 2007, 31, 499-508 [CrossRef]

91. Kelly, J.; Williams, P.W. Modelling tourism destination energy consumption and greenhouse gas emissions: Whistler, British Columbia, Canada. J. Sustain. Tour. 2007, 15, 67-90. [CrossRef]

92. Moscardo, G. Sustainable Luxury in Hotels and Resorts: Is It Possible? In Sustainable Management of Luxury; Springer: Singapore, 2017; pp. 163-189.

93. Roby, H. Understanding the development of business travel policies: Reducing business travel, motivations and barriers. Transp. Res. Part A Policy Pract. 2014, 69, 20-35. [CrossRef]

94. Kask, S.; Kull, T.; Orru, K. Understanding of sustainable tourism among Russian tourism managers. Eur. J. Tour. Res. 2016, 14, 101-105.

95. Randolph, K.A.; Myers, L.L. Basic Statistics in Multivariate Analysis; Oxford University Press: New York, NY, USA, 2013.

96. Khalina, E.V.; Solovjova, J.N.; Yuldasheva, O.U.; Pogrebova, O.A. Values of sustainable development in consumer behavior: Case of Russia. Rev. Espac. 2017, 38, 21.

97. Kennedy, E.H.; Beckley, T.M.; MacFarlane, B.M.; Nadeau, S. Why we don't "walk the talk": Understanding the environmental values/behavior gap in Canada. Hum. Ecol. Rev. 2009, 16, 151-160.

98. Blasch, J.; Farsi, M. Context effects and heterogeneity in voluntary carbon offsetting-A choice experiment in Switzerland. J. Environ. Econ. Policy 2014, 3, 1-24. [CrossRef]

99. Salazar, J.; Husted, B.W.; Biehl, M. Thoughts on the evaluation of corporate social performance through projects. J. Bus. Ethics 2012, 105, 175-186. [CrossRef] 